\title{
Lapita maritime adaptations and the development of fishing technology: A view from Vanuatu
}

\author{
Rintaro 0no, Stuart Hawkins and Stuart Bedford
}

\begin{abstract}
It is now more than 20 years since the last detailed review of Lapita fishing strategies (Butler 1994). Since that time a greater number of Lapita sites have been excavated, some of which have produced substantial fish remains and associated fishing gear. This additional data is essential in providing a more robust understanding of Lapita fishing and its later adaptations throughout the entirety of its distribution. Localised and detailed studies of larger fish vertebrate and technology data sets from a wider range of island groups is crucial to this understanding. Here we present the results of the analysis of a large collection of fish bone from a Lapita and Post-Lapita site on the island of Uripiv, north-east Malakula, Vanuatu. Recovered fishhooks are also outlined. The results, when discussed in the wider Lapita context, suggest the use of a diverse array of technology and capture methods with similarities and differences between regions and temporal periods that may reflect cultural flexibility in response to differences in local marine habitats.
\end{abstract}

\section{Introduction}

The past three decades of zooarchaeological investigation of Lapita sites have revealed that Lapita fishing was mainly practised in inshore coral-reef environments, especially during the first era of migration about 3300 to 2800 BP (cf. Butler 1988, 1994; Clark and Szabó 2009; Green 1979, 1986; Kirch 1988, 1997, 2000; Kirch and Dye 1979; Kirch and Yen 1982; Summerhayes et al. 2010). Yet direct and indirect evidence suggests that Lapita people exploited both near-shore and off-shore marine environments, using a variety of fishing methods including angling, trolling, netting, poison, spears and traps (Butler 1994; Green 1986; Kirch 1997, 2000; Ono 2003; Walter 1989).

The archaeological, ethnographic and linguistic evidence indicates that these sophisticated fishing practices likely allowed the adaptation by Lapita colonists to any marine environment that they encountered. Fishhooks, lures and possible net sinkers have been excavated from some Lapita sites (cf. Butler 1994; Kirch 1997, 2000; Kirch and Dye 1979; Szabó and Summerhayes 2002). Indirect evidence of Lapita fishing strategies generated through linguistic evidence (Walter 1989:138) has both corroborated the direct evidence and suggested a variety of other techniques used by early Oceanic speakers that are not represented in the archaeological record. 
Ethnoarchaeological studies have also been of great assistance in studying the methods currently used by traditional Oceanic fishermen throughout the Asia-Pacific to interpret fish-capture methods within a range of marine habitats (Kirch and Dye 1979; Masse 1986; Ono 2010).

However, much of this research has been focused on Near Oceania, along with a limited number of sites in Remote Oceania (Vanuatu, New Caledonia, Fiji and Tonga). Vanuatu, despite its critical location at the gateway to Remote Oceania, has been under-represented in the literature. Here we begin the process of rectifying this discrepancy so that we can examine the development through zooarchaeological and fishing technology analyses of contingent Lapita maritime adaptations in Vanuatu during the initial colonising phase and during the subsequent 1000 years of settlement.

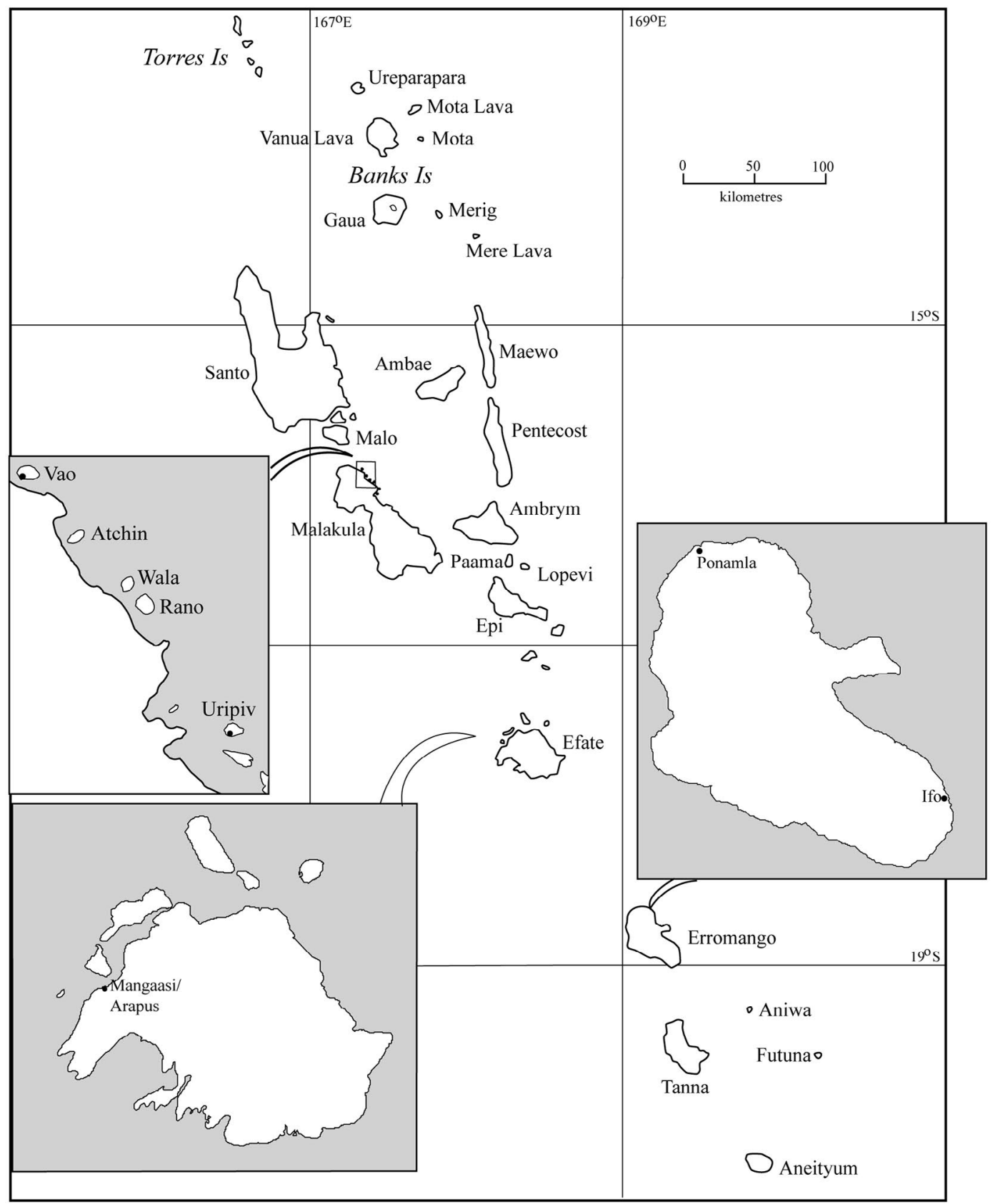

Figure 20.1. Vanuatu and archaeological sites where fish remains have been recovered.

Source: Illustration by the authors. 
First, we review the archaeological evidence of fish exploitation in Lapita sites across the Pacific to provide a context for the extent of Lapita fishing strategies in different marine environments. We then report the results of our analysis of fish bones and related artefacts from Lapita and Post-Lapita contexts from two key sites on Uripiv and Vao (Figure 20.1), both small islets $<2 \mathrm{~km}^{2}$ in area, located off the north-east coast of Malakula in northern Vanuatu (Bedford 2003, 2007). Analyses conducted include the taxonomic identifications of abundant fish vertebrate remains from Uripiv (number of identified specimens $(\mathrm{NSIP})=11$ 754) as well as shell fishhooks, from both Lapita and Post-Lapita contexts on Uripiv and Vao. Finally, in the discussion we compare our Uripiv results with similar data from other sites in Vanuatu (Figure 20.1) where various Lapita and Post-Lapita stratified contexts have been excavated and fish bones recovered since the mid1990s (Bedford 2006:231-236; Bouffandeau et al. 2018). Although this is a necessary exercise, we are also aware of the deficiencies of the previously reported samples that include both small sample size, particularly any Lapita component, and very different site locations. The Vanuatu collections include the Post-Lapita sites of Arapus (collection from 1999 excavations NISP=1428; 2001-2003 excavations NISP $=8080)$ and Mangaasi (NISP=3389) on Efate Island, and cave sites on Malakula (NISP=239). The Arapus 2001-2003 collections have recently been published (Bouffandeau et al. 2018). Stratified sites with Lapita and Post-Lapita deposits include Ponamla (NISP=1937) and Ifo (NISP=128) on Erromango Island in the south. The fish bones from all these sites were identified by Foss Leach and others at the Museum of New Zealand Te Papa Tongarewa (Bedford 2006:231-236; Leach and Budec-Piric n.d.; Leach et al. 1998). In this study we exclude Vanuatu fish bone assemblages from our review that are small $(<1000$ NISP), which includes the assemblages from the Malakula cave sites and Ifo.

\section{Lapita fishing strategies: A current view}

The only detailed review of Lapita fishing strategies remains that of Butler published over 20 years ago (1994). It explicitly linked feeding behaviour of particular fish families with fish-capture methods, based on ethnographic studies of fish-capture techniques (e.g. Kirch and Dye 1979; Wright and Richards 1985) and then applied that framework to interpret the nine quantified Lapita archaeofaunal assemblages available at the time. The sites investigated spanned the entire region of Lapita expansion from the Mussau Islands, Papua New Guinea, to Tonga in Western Polynesia, a distance of $4500 \mathrm{~km}$. In this way, Butler was able to discuss, with some assurance, generalised Lapita fishing strategies in different regions of Oceania (Butler 1994). What she discovered was a difference between western Melanesian assemblages, which comprised similar frequencies of carnivores and herbivores/omnivores, and Eastern Lapita site assemblages that were dominated by herbivores/omnivores (Figure 20.2). This indicated that the major fishing methods practised in Western Lapita sites were more diversified and could have included both angling, netting and spearing methods, while netting and spearing methods were likely to have been more important in Eastern Lapita sites. It was suggested that this could either be a result of differences in marine environments between these regions or it may reflect changing spatiotemporal complexities from west to east that reflect a change in socioeconomic conditions. 


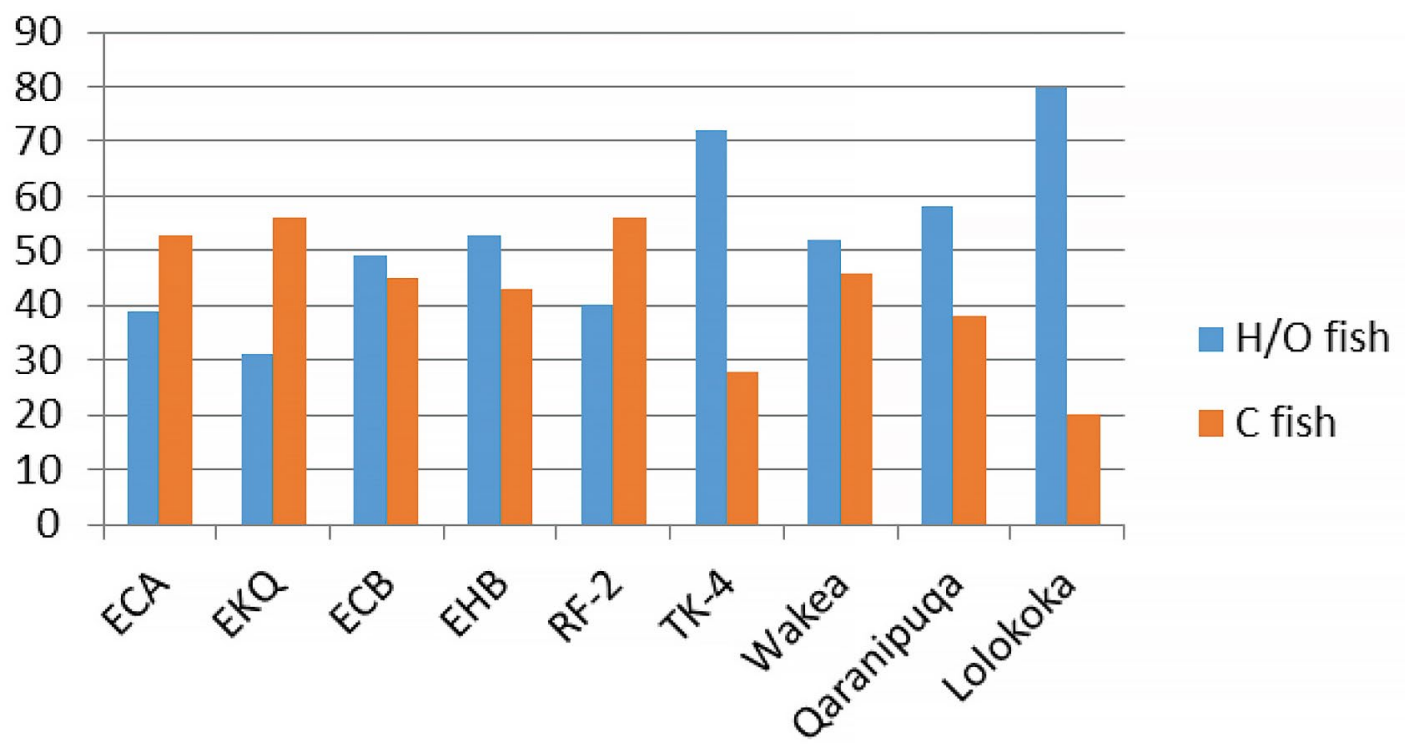

Figure 20.2. Relative proportion of fish remains by fish feeding strategies in nine Lapita sites identified by Butler (1994).

ECA, ECB, EHB, EKQ are located in the Mussau Islands (Kirch 1997); RF-2 is located in the main Reef Islands of the Santa Cruz Group, with TK-4 located in Tikopia; Wakea and Qaranipuqa are located on Lakeba in Fiji; and Lolokoka (NT-90) is located in Niuatoputapu (see also Figure 20.7).

Source: Chart prepared by the authors.

However, Butler recognised that the study did not reflect the full picture of Lapita fishing strategies, as certain regional gaps existed, with some regions significantly under-represented. The result was the conflating of space and time into generalised Western and Eastern Lapita regions that had the effect of obscuring variation in Lapita fishing behaviour. Among the nine sites compared, four sites were located in the Mussau Islands in Near Oceania, while the other five were in Remote Oceania-namely the Reefs-Santa Cruz Islands and Tikopia (2), in the southeast Solomon Islands, Fiji (2) and Niuatoputapu in Tonga (1). However, it should be noted that there was a consequential unevenness in the distribution of the total number (NISP=5266) of fish bones recovered from these Lapita sites, with over 93 per cent concentrated in the Mussau $(\mathrm{NISP}=3777)$ and Tikopia (NISP=1136) assemblages alone. At the time of the study, no fish remains from either Vanuatu or New Caledonia were included.

To provide a more robust understanding of Lapita fishing and its later adaptations throughout the entirety of its distribution, more localised and detailed studies of larger fish vertebrate and technology datasets from a wider range of island groups are required. The varying influences of contrasting marine environments and cultural developments over such an extensive region can then be better assessed along with an account of how fishing practices changed over time. 


\section{Materials and methods}

\section{Uripiv excavations 2001-2002, 2005 and 2009}

We focus on the results of analyses of the fish bones recovered from excavations on Uripiv Island, since this site has produced by far the largest number of fish bones from a Lapita site in the Pacific to date ( $\mathrm{N}=11754$ for 2001-2009 excavations), nearly doubling the combined total of fish bones recovered from all Lapita sites. Vao has also produced abundant quantities of fish remains, but the analysis is not yet complete and will be reported on elsewhere.

Excavations on Uripiv Island were carried out over a number of field seasons. Those of 2001-2002 and 2005 totalled fifteen $1 \mathrm{~m}^{2}$ test pits (TPs 1-15) excavated across the site along with another three $2 \mathrm{~m}^{2}$ areas (Areas A, B, C), a total excavation area of $27 \mathrm{~m}^{2}$ (Figure 20.3). This excavation strategy established that the core of the Lapita site, as defined by midden deposits and activity areas, comprising hearth and firescoop features, covered an area of some $2800 \mathrm{~m}^{2}$ (Bedford et al. 2011). Lapita and Post-Lapita period burials were identified, as well as habitation areas that produced a wide range of material culture, including pottery, stone and shell artefacts (Bedford 2003, 2007; Bedford et al. 2011; Kononenko et al. 2010). Midden remains were abundant and included marine resources (fish, shell, sea turtle) as well as native terrestrial resources such as fruit bat, large tortoise (Hawkins et al. 2016) and bird, as well as introduced domesticates (pig, rat and chicken) (Bedford 2003; Hawkins unpublished data). These excavations confirmed that the Uripiv Lapita site is now situated $50 \mathrm{~m}$ from the sea and the current ground surface is $6-7 \mathrm{~m}$ above mean sea level. In 2009 a further $27 \mathrm{~m}^{2}$ of the site was excavated, comprising a 2 by $3 \mathrm{~m}$ area (D) located next to TP1, a 3 by $5 \mathrm{~m}$ area (E), adjacent to TP 14 and a 2 by $3 \mathrm{~m}$ area (F) located near TP9 (Figure 20.3). Further areal excavations were undertaken on Uripiv in 2010-2011, but analysis of these excavations is ongoing and here we report and discuss only the excavated fish remains from 2001-2002, 2005 and 2009. All excavations were undertaken by trowel and material was sieved in water in $2 \mathrm{~mm}$ sieves to achieve a high level of recovery.

The stratigraphy of the Lapita site on Uripiv consists of five principal layers with some minor variation across the site (Horrocks and Bedford 2005). Layer 1 comprises humic topsoil and in some areas historic coral gravel house floors are present. Layer 2 is a dark brown tephrarich deposit containing limited artefactual material, including both Malakula ceramics dating to the last 2000 years and occasional historic items. Layer 3 contains very compacted and locally imported worn branch coral and pebbles and associated cultural material that dates to c. 23002000 BP. Layer 4 is a concentrated Lapita midden in a sand and soil matrix dated around 2850 to 2600 BP, and Layer 5 is the original sterile coral beach sand (Bedford et al. 2011; Horrocks and Bedford 2005; Horrocks et al. 2009), which contains Lapita cultural materials that have been compressed into its strata from the layer above. 


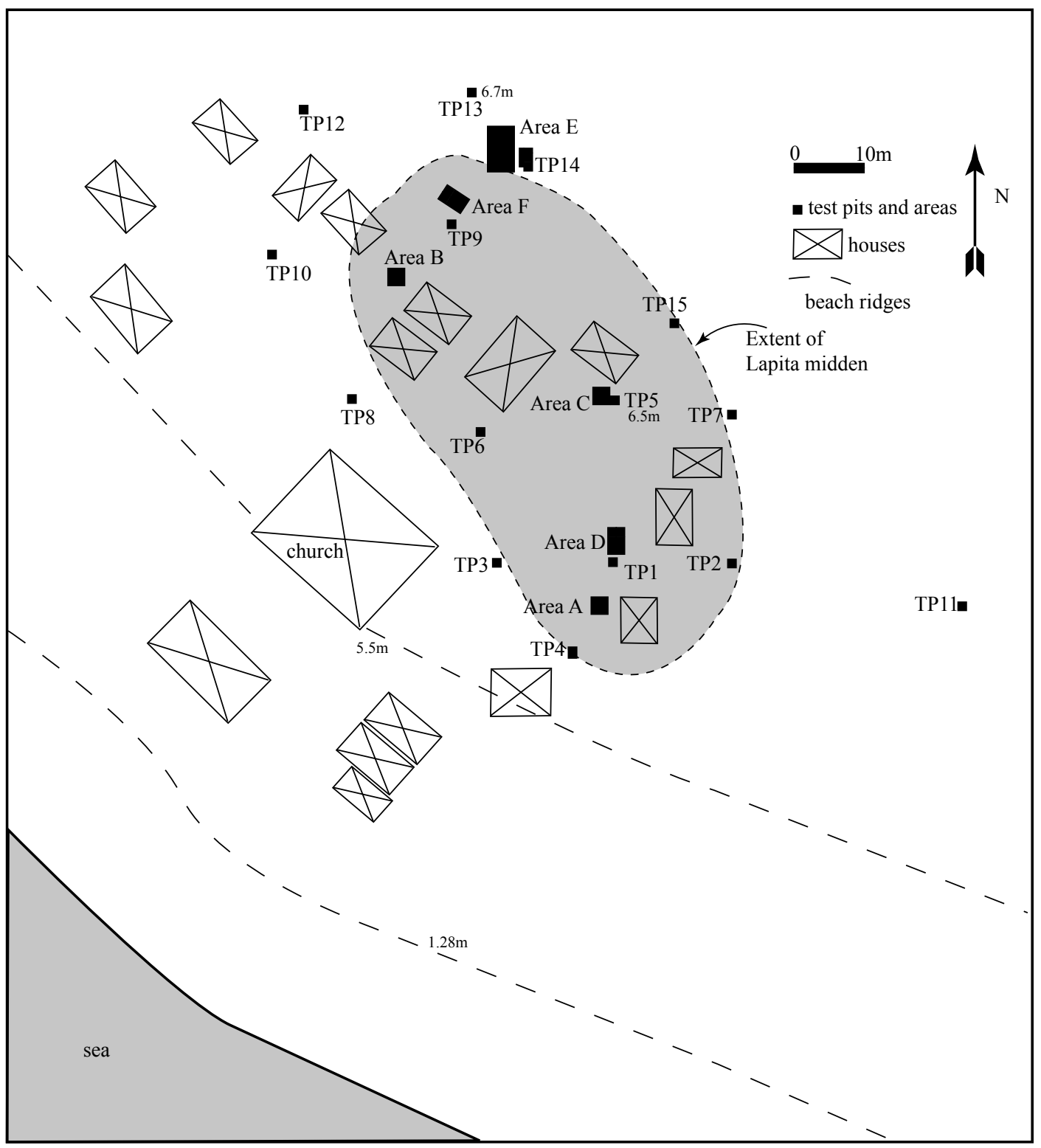

Figure 20.3. Location of excavated areas and extent of Lapita site, Uripiv Island.

Source: Illustration by the authors.

The radiocarbon dates from Uripiv and Vao indicate that initial arrival and the Lapita phase occupation at the sites broadly spans the period 2900-2600 years cal. BP, although the flat section of the calibration curve at $2500 \mathrm{BP}$ makes further precision difficult. Vao appears to be a slightly earlier Lapita site than Uripiv based on the recovered Lapita ceramics, which demonstrate a greater range of vessel form and finer dentate decoration, and distinctive faunal remains, particularly the marked abundance of tortoise bone recovered from Vao (Hawkins et al. 2016). The Post-Lapita phase is evident across both sites to around 2000 BP (Bedford et al. 2011) when massive volcanic activity from the nearby island of Ambrym instigates major change (Robin et al. 1993). Nucleated settlement that had remained in the same coastal locales for some 1000 years became more dispersed across both islands following the volcanic disturbances. At European contact, settlement was spread across the interior of both islands comprising 6-7 villages associated with ceremonial centres (Layard 1942:53-57). 


\section{Fish capture reconstruction}

Comparative taxonomic morphological analysis between archaeological material and reference specimens was done using The Australian National University reference collection housed at the Department of Archaeology and Natural History Osteology laboratory. We identified fish bones from Uripiv using the methods developed by Ono and others for analysing tropical fish remains from Island Southeast Asia (e.g. Campos 2009; O’Connor et al. 2011; Ono 2003, 2004; Samper Carro et al. 2016) and Oceania (e.g. Butler 1988; Lambrides and Weisler 2015a, 2015b; Leach 1986; Leach and Davidson 1977; Masse 1989; Ono and Intoh 2011; Vogel 2005; Walter 1989).

Identifications were based on cranial elements, special elements, vertebrae and teeth. Cranial elements we could use in this study were the maxilla, premaxilla, dentary, articulate, quadrate, pharyngeal cluster, opercular, preopercular, hyomandibular, palatine, cleithrum, supracleithrum, post-temporal, scapula, ephiyal and ceratohyal. Special elements identified in this study were the dorsal spines of Balistidae (triggerfishes), Acanthuridae (unicornfishes) and Holocentridae (squirrelfishes), dermal scales of Ostraciidae (boxfishes), dorsal spines of Diodontidae (porcupinefishes), and scutes (and dorsal scutes) of Acanthuridae and Carangidae (jacks and trevallies). Vertebrae (thoracic and caudal peduncles) were used for the identification of Elasmobranchii (sharks/rays) and some bony fish families including Scombridae (tunas, mackerels and bonitos), Muraenidae (moray eels), Acanthuridae, Balistidae and Scaridae (parrotfishes), which are similarly identified in other Pacific islands (e.g. Lambrides and Weisler 2015a, 2015b; Ono and Clark 2010; Ono and Intoh 2011). The minimum number of individuals (MNI) and number of identified specimens (NISP) were calculated (e.g. Leach 1986), although element size mismatches were also considered (e.g. Ono 2003, 2004, 2006; Ono and Intoh 2011). For Diodontidae, fish spines ( $\mathrm{n}=772$ or see Table 20.3) were excluded from assessments of taxonomic relative abundance as they are known to drastically overinflate NISP counts relative to other taxa (Vogel 2005).

To reconstruct general fishing methods undertaken in the past at Uripiv accurately, one must consider the feeding behaviour of fish, habitat and fishing gear recovered from the sites. We classified identified taxa based on feeding behaviour as (1) herbivore, (2) omnivore and (3) carnivore. Many previous studies (e.g. Butler 1994; Kirch and Dye 1979; Masse 1986; Ono $2003,2004,2009,2011)$ indicate that such basic fish diet categories are essential to determine prehistoric capture methods in tropical marine environments. Generally, (1) herbivorous fish are mainly captured by netting, spearing and trapping, but are hard to catch by angling, while (3) carnivorous fish are more easily captured by angling and trolling, and (2) omnivorous fish can be captured by various methods depending on family, species and size. For example, Scarids (parrotfishes) and Acanthurids (unicornfishes, tangs and surgeonfishes), which are both major herbivorous fish families identified in prehistoric Asia-Pacific archaeological sites, are mainly captured by netting or spearing, but rarely in the ethnographic records captured by angling (Table 20.5).

On the other hand, important carnivorous fish taxa such as Serranids (groupers), Lethrinids (emperor fishes) and Labrids (wrasses) are more frequently captured by angling and spearing. Serranids, which especially prefer to inhabit the sea bottom, are usually captured by angling, hence this family can be a key indicator of angling using zooarchaeological data (e.g. Ono 2010). Holocentrids (squirrelfishes) and some larger species of Carangids (jacks, pompanos, jack mackerels) (e.g. Caranxsp.) are also usually captured by angling, using a variety of specific hooks (of relatively small size for Holocentrids) and angling methods, which are ethnographically recorded in Oceania (e.g. Mafutaga-a-Toeaina-o-Atafu-i-Matauala-Porirua 2008; Masse 1986; McAlister 2002; Ono and Addison 2009). Measuring long-term changes in fishing strategies, we used an abundance index (herbivores+omnivores NISP divided by herbivores+omnivores+carnivores 
NISP $x$ 100) to track the ratio of herbivores and omnivores relative to carnivores from the Lapita to Post-Lapita periods. Change over time was statistically quantified using Cochrane's test of linear trends, which is a linear chi-squared test that takes sample size into account (Zar 2010).

\section{Results of the Uripiv fish bone analysis}

A total of 11754 fish bones were quantified in the Uripiv assemblage and the rank of the identified anatomical elements is shown in Table 20.1. Vertebrae were the most common element, while dorsal spines and pharyngeal clusters, as well as the five paired cranial bones including premaxillae, dentaries, maxillae, articulares and quadrates, are also common. These elements are highly distinctive morphologically for taxonomic identification (Table 20.1). Among these, 1912 bones could be identified as representing 19 fish taxa (Table 20.2) including 17 families, the subclass Elasmobranchii, and one species of Lethrinidae as Monotaxis grandoculis (humpnose big-eye bream). These fish bones were recovered from the fifteen $1 \mathrm{~m}^{2}$ test pits (Table 20.3) and the five larger areas (A-E) with a total excavated area of $54 \mathrm{~m}^{2}$ (Table 20.4).

Table 20.1. Rank and number of fish skeletal elements from Uripiv (2002-2009) excavations ( $\mathrm{n}=11758$ ).

\begin{tabular}{|c|c|c|c|c|}
\hline Element & Right & Left & Right/Left & Total \\
\hline Spine/Diodontidae & - & - & 772 & 772 \\
\hline Premaxilla & 72 & 71 & 11 & 154 \\
\hline Dentary & 64 & 79 & 4 & 147 \\
\hline Articulate & 54 & 66 & 5 & 125 \\
\hline Quadrate & 58 & 48 & 5 & 111 \\
\hline Maxilla & 53 & 43 & 5 & 101 \\
\hline Premaxilla/Dentary & - & - & 39 & 39 \\
\hline Dorsal spine/Acnathuridae & - & - & 192 & 192 \\
\hline Dorsal spine/Balistidae & - & - & 83 & 83 \\
\hline Dorsal spine/Holocentridae & - & - & 6 & 6 \\
\hline Dorsal spine & - & - & 3 & 3 \\
\hline Upper pharyngeal/Scaridae & 18 & 16 & 54 & 88 \\
\hline Lower pharyngeal/Scaridae & - & - & 60 & 60 \\
\hline Upper pharyngeal/Labridae & 7 & 5 & 27 & 39 \\
\hline Lower Pharyngeal/Labridae & - & - & 38 & 38 \\
\hline Pharyngeal & - & - & 3 & 3 \\
\hline Pharyngeal cluster/Scaridae & - & - & 9 & 9 \\
\hline Pharyngeal/Lutjanidae & - & - & 1 & 1 \\
\hline Hyomandibular & 12 & 8 & 22 & 42 \\
\hline Cleithrum & 1 & - & 23 & 24 \\
\hline Cleithrum/Acanthuridae & 4 & 3 & 12 & 19 \\
\hline Opercle & 1 & 2 & 17 & 20 \\
\hline Dentary/Premaxilla & - & - & 1 & 1 \\
\hline Dentary or premaxilla/0straciidae & - & - & 16 & 16 \\
\hline Palatine/Lethrinidae & 5 & 6 & 1 & 12 \\
\hline Palatine/Scarids & - & - & 2 & 2 \\
\hline Palatine & - & - & 3 & 3 \\
\hline Preopercle & 3 & 1 & 5 & 9 \\
\hline Scale & - & - & 9 & 9 \\
\hline Scale/Ostraciidae & - & - & 4 & 4 \\
\hline Scute/Acanthuridae & - & - & 11 & 11 \\
\hline
\end{tabular}




\begin{tabular}{|c|c|c|c|c|}
\hline Element & Right & Left & Right/Left & Total \\
\hline Scute/Carangidae & - & - & 4 & 4 \\
\hline Supra-cleithrum & 2 & 2 & 2 & 6 \\
\hline Supra-cleithrum/Serranids & - & 2 & - & 2 \\
\hline Scapula & - & - & 7 & 7 \\
\hline Vomor & - & - & 7 & 7 \\
\hline Epihyal & 1 & 2 & 2 & 5 \\
\hline Epihyal/Lethrinidae & 2 & - & - & 2 \\
\hline Posttemporal & 1 & - & 3 & 4 \\
\hline Basihyal/Balistidae & - & - & 2 & 2 \\
\hline Post-opercle & - & - & 1 & 1 \\
\hline Ceratohyal & 1 & - & - & 1 \\
\hline Pharyngeal cluster/Ostraciidae & - & - & 1 & 1 \\
\hline Ceratohyal/Naso/Acanthurids & - & - & 1 & 1 \\
\hline Vertebra $<5 \mathrm{~mm}$ & - & - & 2335 & 2335 \\
\hline Vertebra 6-9 mm & - & - & 89 & 89 \\
\hline Vertebra >10 mm & - & - & 25 & 25 \\
\hline Vertebra/Scaridae & - & - & 18 & 18 \\
\hline Vertebra/Elasmobranchi & - & - & 9 & 9 \\
\hline Vertebra/Carangidae & - & - & 6 & 6 \\
\hline Vertebra/Balistidae & - & - & 6 & 6 \\
\hline Vertebra/Muraenidae & - & - & 5 & 5 \\
\hline Caudal vertebra/Scaridae & - & - & 38 & 38 \\
\hline Caudal vertebra & - & - & 37 & 37 \\
\hline Spine & - & - & 2016 & 2016 \\
\hline Ribs & - & - & 113 & 113 \\
\hline Tooth/Balistidae & - & - & 21 & 21 \\
\hline Tooth & - & - & 8 & 8 \\
\hline Tooth/Labridae & - & - & 3 & 3 \\
\hline Tooth/Elasmobranchii & - & - & 2 & 2 \\
\hline Tooth/Ray? & - & - & 1 & 1 \\
\hline Tooth/Lethrinidae & - & - & 1 & 1 \\
\hline Undefined fragments & - & - & 4836 & 4836 \\
\hline Total & 359 & 354 & 11042 & 11755 \\
\hline
\end{tabular}

Source: Authors' summary.

Table 20.2. NISP of identified taxa from Uripiv 2001-2005, 2009.

\begin{tabular}{|l|l|c|c|c|c|c|c|c|}
\hline Taxa & Diet & TP 1-14 & A & B & C & D & E & Total \\
\hline Diodontidae/Spine & Omnivore & 179 & 512 & 26 & 1 & 44 & 10 & $\mathbf{7 7 2}$ \\
\hline Diodontidae & Omnivore & 13 & 10 & 19 & 0 & 0 & 0 & $\mathbf{4 2}$ \\
\hline Scaridae & Herbivore & 96 & 22 & 4 & 2 & 204 & 22 & 350 \\
\hline Acanthuridae & Herbivore & 44 & 13 & 19 & 1 & 109 & - & 186 \\
\hline Labridae & Carnivore & 88 & 19 & 1 & 2 & 69 & - & $\mathbf{1 7 9}$ \\
\hline Lethrinidae & Carnivore & 82 & 14 & 10 & 5 & 44 & - & $\mathbf{1 5 5}$ \\
\hline Balistidae & Omnivore & 51 & 12 & 13 & 2 & 56 & - & $\mathbf{1 3 4}$ \\
\hline Serranidae & Carnivore & 9 & 3 & 2 & - & 7 & - & $\mathbf{2 1}$ \\
\hline Ostraciidae & Omnivore & 12 & 1 & - & - & 5 & - & $\mathbf{1 8}$ \\
\hline Carangidae & Carnivore & 4 & 1 & 2 & - & 8 & - & $\mathbf{1 5}$ \\
\hline Lutjanidae & Carnivore & 6 & - & - & - & 8 & - & $\mathbf{1 4}$ \\
\hline
\end{tabular}




\begin{tabular}{|l|l|c|c|c|c|c|c|c|}
\hline Taxa & Diet & TP 1-14 & A & B & C & D & E & Total \\
\hline Holocentridae & Carnivore & 6 & 1 & 3 & - & - & - & 10 \\
\hline Tetradontidae & Omnivore & 1 & - & - & - & 9 & - & 10 \\
\hline Elasmobranchi & Carnivore & 3 & - & - & - & 7 & - & 10 \\
\hline Muraenidae & Carnivore & 4 & 2 & - & - & 3 & - & 9 \\
\hline Haemuridae & Carnivore & 0 & 6 & 1 & - & - & - & 7 \\
\hline Kyophosidae & Herbivore & 5 & - & - & - & - & - & 5 \\
\hline Monotaxis sp. & Carnivore & 0 & - & - & - & 3 & - & 3 \\
\hline Muliidae & Carnivore & 2 & - & - & - & 1 & - & 3 \\
\hline Pomacentridae & Omnivore & 0 & - & 1 & - & - & - & 1 \\
\hline Total & & 605 & 616 & 101 & 13 & 577 & 32 & 1944 \\
\hline
\end{tabular}

Source: Authors' summary.

Here we summarise the 15 test pits that were excavated across the site to determine the extent of the Lapita settlement (see Figure 20.3). TPs 8 and 9 produced the largest number of fish remains, while TPs 3, 11 and 14 produced relatively fewer numbers of fish bones, and no fish bones were recovered from TP15 (Table 20.3). This correlates with diminishing quantities of other midden deposits from these test pits that mark the periphery of the Lapita phase settlement. In terms of temporal changes in the quantity of recovered fish bones, it was the Lapita Layer 4 where bones were the most ubiquitous. TPs 1, 3, 4, 6, 9 and 10 produced fish bones from the Lapita period while TPs 2, 7, 8, 11 and 13 produced fish bones mainly from Layer 3, dated to the Post-Lapita period between 2300 and $2000 \mathrm{BP}$. The fish bones from the five larger excavation areas A to E produced the most abundant fish bone deposits (NISP $=7563$ ). Most fish bones in Area D are from Lapita Layers 4 and 5, while in Areas A, B and E (Table 20.4) bones were also recovered from the Post-Lapita Layer 3. Area C produced only a few fish bones from Lapita Layers 4 and 5.

Table 20.3. NISP of fish remains in each Layer from TP 1 to TP 15 (2001-2005).

\begin{tabular}{|l|c|c|c|c|c|c|c|c|c|c|c|c|c|c|l|}
\hline Layer/TP & TP1 & TP2 & TP3 & TP4 & TP5 & TP6 & TP7 & TP8 & TP9 & TP10 & TP11 & TP13 & TP14 & Total & Age \\
\hline Layer 1 & - & - & - & - & - & - & - & - & - & - & - & - & - & - & - \\
\hline Layer 2 & 8 & - & - & 1 & - & - & 1 & 2 & 1 & 4 & - & - & - & 17 & after 2000 BP \\
\hline Layer 3 & - & 306 & - & - & - & - & 46 & 515 & - & - & 6 & 272 & - & 1145 & $2300-2000$ BP \\
\hline Layer 4 & 190 & 55 & 87 & 26 & 434 & 221 & 131 & 492 & 690 & 234 & - & - & 3 & 2563 & Lapita \\
\hline Layer 5 & 12 & - & 17 & 142 & - & 1 & - & - & 238 & 117 & - & - & & 527 & Lapita \\
\hline Total NISP & $\mathbf{2 1 0}$ & $\mathbf{3 6 1}$ & $\mathbf{1 0 4}$ & $\mathbf{1 6 9}$ & $\mathbf{4 3 4}$ & $\mathbf{2 2 2}$ & $\mathbf{1 7 8}$ & $\mathbf{1 0 0 9}$ & $\mathbf{9 2 9}$ & $\mathbf{3 5 5}$ & $\mathbf{6}$ & $\mathbf{2 7 2}$ & $\mathbf{3}$ & $\mathbf{4 2 5 2}$ & \\
\hline
\end{tabular}

No fish bones were recovered from TPs 12 and 15.

Source: Authors' summary.

Table 20.4. NISP of fish remains from Areas A to E on Uripiv Island.

\begin{tabular}{|l|c|c|c|c|c|c|l|}
\hline Layer/TP & $\mathbf{A}$ & $\mathbf{B}$ & $\mathbf{C}$ & $\mathbf{D}$ & $\mathbf{E}$ & Total & Age \\
\hline Layer 1 & - & - & - & - & - & - & - \\
\hline Layer 2 & - & - & - & 1 & - & 1 & after 2000 BP \\
\hline Layer 3 & 958 & 299 & - & - & 46 & 1303 & 2300-2000 BP \\
\hline Layer 4 & 86 & 533 & 51 & 3061 & 255 & 3986 & Lapita \\
\hline Layer 5 & 401 & 89 & 17 & 1714 & - & 2221 & Lapita \\
\hline Total & $\mathbf{1 4 4 5}$ & $\mathbf{9 2 1}$ & $\mathbf{6 8}$ & $\mathbf{4 7 7 6}$ & $\mathbf{3 0 1}$ & $\mathbf{7 5 1 1}$ & \\
\hline
\end{tabular}

Source: Authors' summary. 
Regarding the relative abundance of the major fish species in Uripiv, the largest number of bones by NISP identified to taxa belongs to Diodontidae (see Table 20.2), but most of these identified elements are spines $(n=504)$, vastly overinflating its abundance relative to other taxa. When Diodontidae spines (NISP=102) are excluded, this problem is bypassed, and ranked taxa in order of abundance by NISP at Uripiv are Scaridae, Labridae, Lethrinidae and Diodontidae, followed by Acanthuridae and Balistidae. They are all inshore fish species that mainly inhabit shallow marine reef platforms. However, these taxa differ in their major capture methods based on their specialised feeding behaviours. For example, Scaridae and Acanthruridae are mainly captured by netting and spearing, while Labridae and Balistidae are more easily captured by angling and spearing. Lethrinidae are one of the major fish families represented at Uripiv, as they are in other Lapita sites both in Vanuatu and elsewhere. This family can be captured by both angling and netting, depending on the species and size of the species caught (see Table 20.7), judging from ethnoarchaeological research on Sama fishing in coastal Borneo (Ono 2010). Outer-reef to pelagic species like Carangidae, Scombridae and Selachimorpha (sharks) were not very well represented in the Uripiv assemblage. The minor role of outer-reef to pelagic fish species in marine foraging during Lapita and Post-Lapita settlement of Uripiv is similar to most other Lapita sites both in Vanuatu and other islands.

Table 20.5. Relationship between major fish diet and capturing methods based on ethnographic records.

\begin{tabular}{|l|c|l|c|l|c|l|c|}
\hline Hook and line & Diet & Trolling & Diet & Trap & Diet & Net/spear & Diet \\
\hline Lethrinidae & C & Sphrynaenidae & C & Muraenidae & C & Scaridae & H \\
\hline Labridae & C & Scombridae & C & Balistidae & O & Siganidae & H \\
\hline Holocentridae & C & - & - & - & - & Diodontidae & O \\
\hline Serranidae & C & - & - & - & - & Mugilidae & H \\
\hline Haemulidae & C & - & - & - & - & Kyophosidae & H \\
\hline Carangidae & C & - & - & - & - & Tetradontidae & 0 \\
\hline Belonidae & $\mathrm{C}$ & - & - & - & - & Ostraciidae & 0 \\
\hline- & - & - & - & - & - & Balistidae & 0 \\
\hline- & - & - & - & - & - & Lethrinidae (small) & C \\
\hline- & - & - & - & - & - & Labridae (small) & C \\
\hline- & - & - & - & - & - & Mullidae & C \\
\hline
\end{tabular}

$\mathrm{C}=$ carnivores, $\mathrm{H}=$ herbivores, $0=0$ mnivores.

Source: Data generated from Butler 1994; Masse 1986; 0no 2010.

In Figure 20.4, we combined (1) herbivore and (2) omnivore fish species (in blue), which include Scarids, Diodontids, Acanthurids, Balistids etc, and compared these with (3) carnivorous fish (in red), which mainly include Lethrinids, Labrids, Serranids and Carangids. The results indicate that angling, netting or spearing were used equally to catch inshore fish species throughout prehistory on Uripiv, judging by the equal proportions of herbivores/omnivores to carnivores for Layer 3 (Post-Lapita), Layer 4 (Lapita) and Layer 5 (Lapita).

Statistical testing confirms that there was no significant temporal change in the relative proportions of herbivores/omnivores and carnivores over Lapita and Post-Lapita periods, suggesting that there was no significant change in fishing practices (e.g. netting and spearing versus angling) at Uripiv over time (Figure 20.5; $\mathrm{X}^{2}$ trend=0.493, $\mathrm{P}=0.483$ ). This suggests that the basic character of prehistoric fish exploitation at Uripiv was mostly influenced by the local marine environment, which appears to have been stable in its ecological composition over time. 

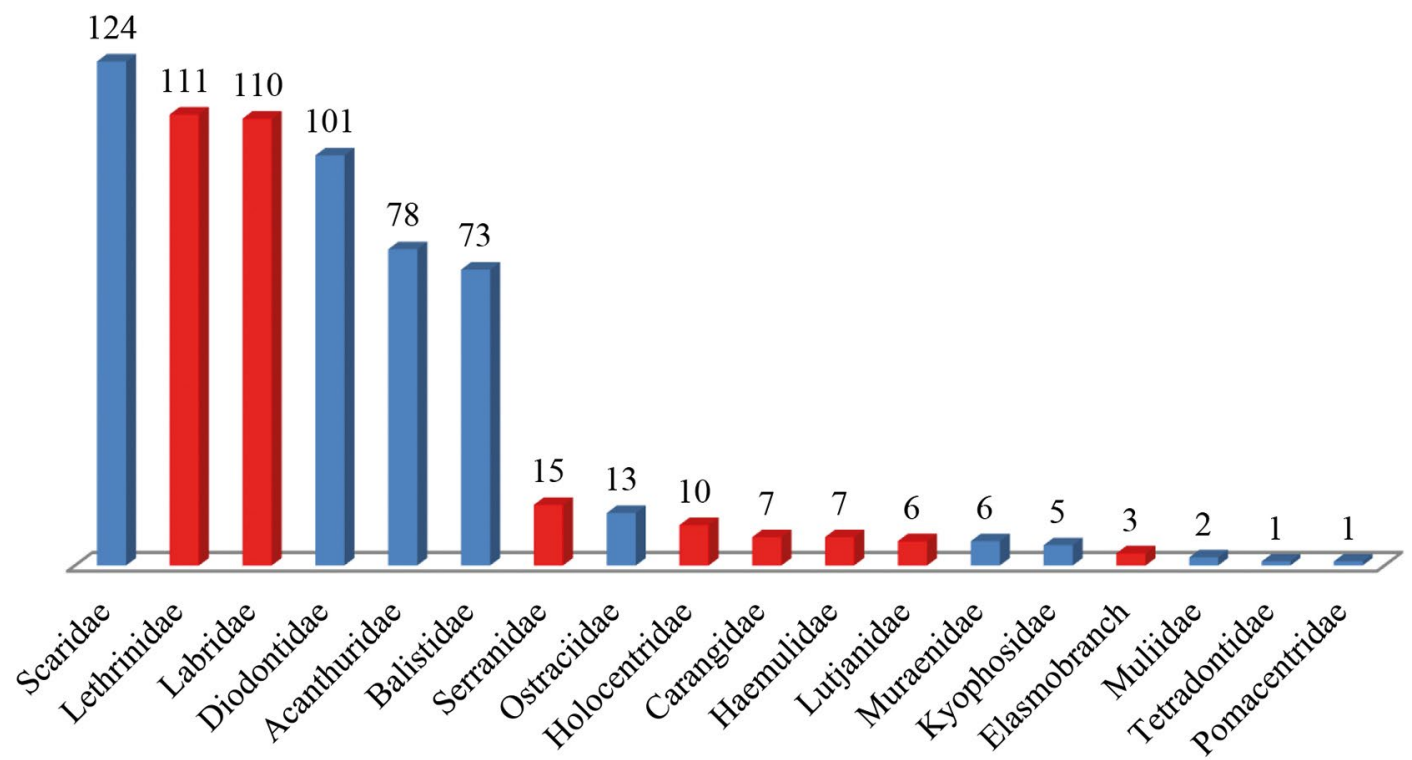

Figure 20.4. Rank order of Uripiv fish families based on NISP (except Diodontidae, which is counted in $\mathrm{MNI})$.

blue=herbivore/omnivore fishes; red=carnivorous fishes.

Source: Chart prepared by the authors.

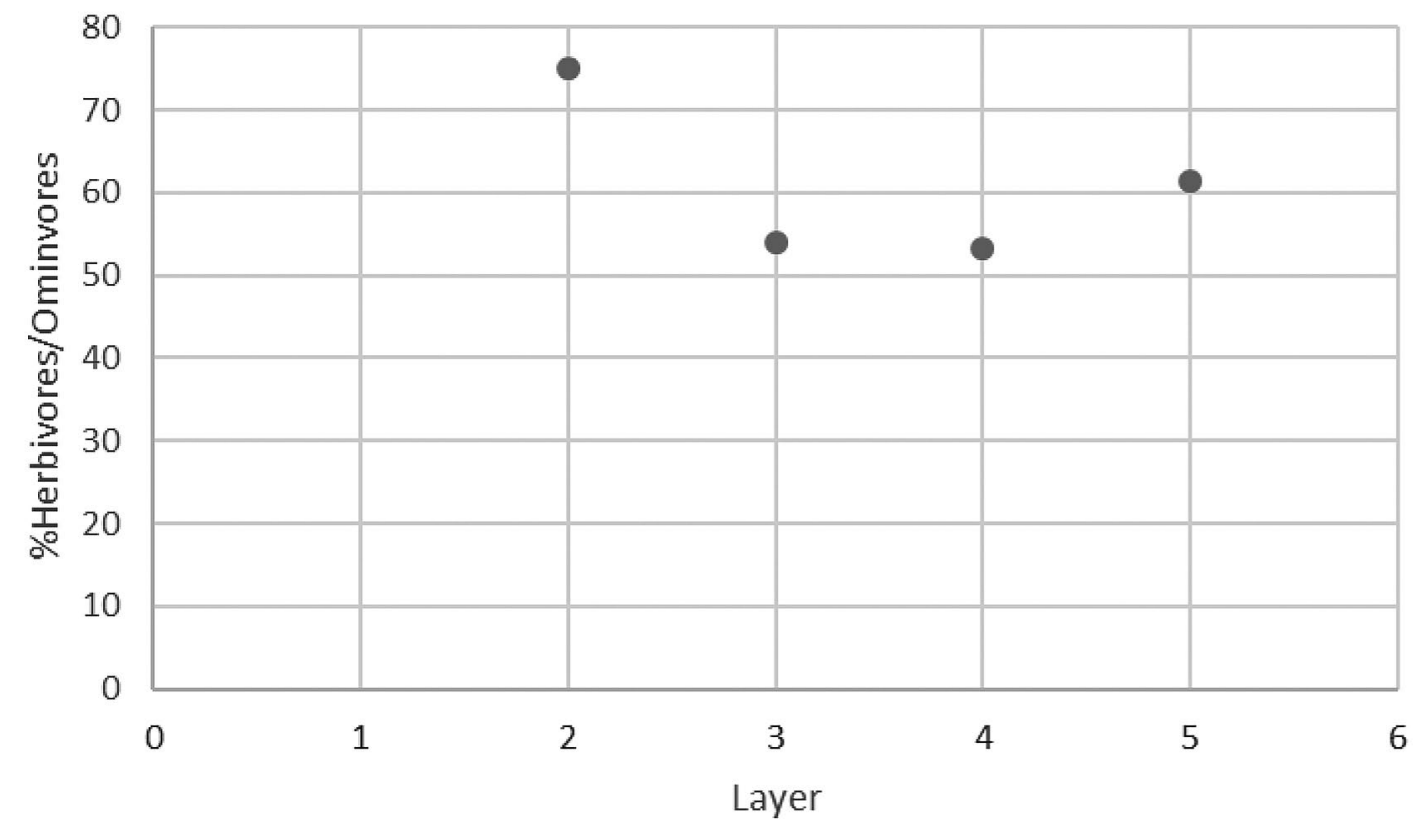

Figure 20.5. Changes in fish-capture methods at Uripiv as expressed by the proportion of herbivore and omnivore NISP (MNI in the case of Diodontidae) relative to carnivore NISP (herbivore+omnivore NISP divided by (herbivore+omnivore+carnivore NISP) $x 100$ ).

$\mathrm{X}^{2}$ trend $=0.493, \mathrm{P}=0.483$.

Source: Chart prepared by the authors. 


\section{Excavated fishhooks from Uripiv and Vao}

Here we describe the shell fishhooks and a possible lure tab from Uripiv, along with fishhooks and a lure recovered from nearby Vao Island (Table 20.6). First, two fishhooks and a lure were recovered at Uripiv. One was a small broken one-piece Trochus shell fishhook recovered from Post-Lapita deposits (Figure 20.6a). It is shaped like a jabbing-type fishhook that could be employed to catch fish in shallow water (e.g. Reinman 1965, 1967). Judging from its size, it could have been useful for catching small-sized carnivore and surface swimmer species such as Carangids and Holocentrids. A possible Trochus shell hook tab from the Post-Lapita layer seems to have similar size, but its shape looks more like a rotating type that could be employed to catch bottom-swimming fish taxa such as Labrids and Serranids (Figure 20.6b). Both types of fishhooks have also been recovered from Vao and other Lapita sites, including Kamgot and Tamuarawai in the Bismarck Archipelago (Summerhayes et al. 2010; Szabó 2010), Bourewa in Fiji (Ishimura 2010; Nunn et al. 2004, 2006), and Nukuleka and Tufu Mahina on Tongatapu, Tonga (Poulsen 1987). A single unfinished Trochus shell trolling lure tab was excavated on Uripiv Island, from the Lapita Layer in Area D (Figure 20.6c). It appears to match an almost complete Trochus shell lure-hook with finely carved notches (possibly for attaching both line and hackles such as feather or pig bristles) excavated from Lapita contexts on Vao (Figure 20.6e-f). These lures may have a possible relationship with Trochus lure-hooks excavated from the Lapita sites in the Mussau Islands in the Western Lapita region (e.g. Kirch 1997, 2000, or see Figure 20.9). Since such possible trolling lure-hooks were all excavated from the earliest Lapita Layers on Uripiv and Vao, this type could have been one of the most important pieces of fishing gear used during this period, implying that changes in fishing technology and capture methods occurred soon after initial settlement of the archipelago. Along with the lures from Vao, there were three pieces of complete one-piece hooks, two broken one-piece hooks and two fishhook tabs (see Table 20.6 and Figure 20.6d-f).

Table 20.6. List of the excavated fishhooks from Uripiv and Vao Islands.

\begin{tabular}{|l|l|l|l|l|l|}
\hline \multicolumn{7}{|l|}{ Fishhook type } & Site & Layer & Level & Material & Age \\
\hline Uripiv & Area D3 & 5 & 1 & Trochus sp. & Initial-Lapita \\
\hline One-piece trolling hook tab & Area E & 3 & Feature 4 & Trochus sp. & Post-Lapita \\
\hline Broken one-piece hook & Area A & 3 & $80-90 \mathrm{~cm}$ & Trochus sp. & Post-Lapita \\
\hline Broken one-piece hook & TP 19A & 5 & & Trochus niloticus & Initial-Lapita \\
\hline Vao & A5 & 4 & $70-80 \mathrm{~cm}$ & Trochus sp. & Lapita \\
\hline One-piece trolling hook & ST11 & 4 & $100-110 \mathrm{~cm}$ & Trochus sp. & Late-Lapita \\
\hline Fishhook tab & Area A & 3 & Burial 2 & Trochus sp. & Post-Lapita \\
\hline Broken one-piece hook & ST 11 & 3 & $80-90 \mathrm{~cm}$ & Trochus sp. & Post-Lapita \\
\hline One-piece shell hook & A2 & 3 & $50-60 \mathrm{~cm}$ & Trochus sp. & Post-Lapita \\
\hline One-piece shell hook & A2 & 3 & $50-60 \mathrm{~cm}$ & Trochus sp. & Post-Lapita \\
\hline Broken one-piece hook
\end{tabular}

Source: Authors' summary. 


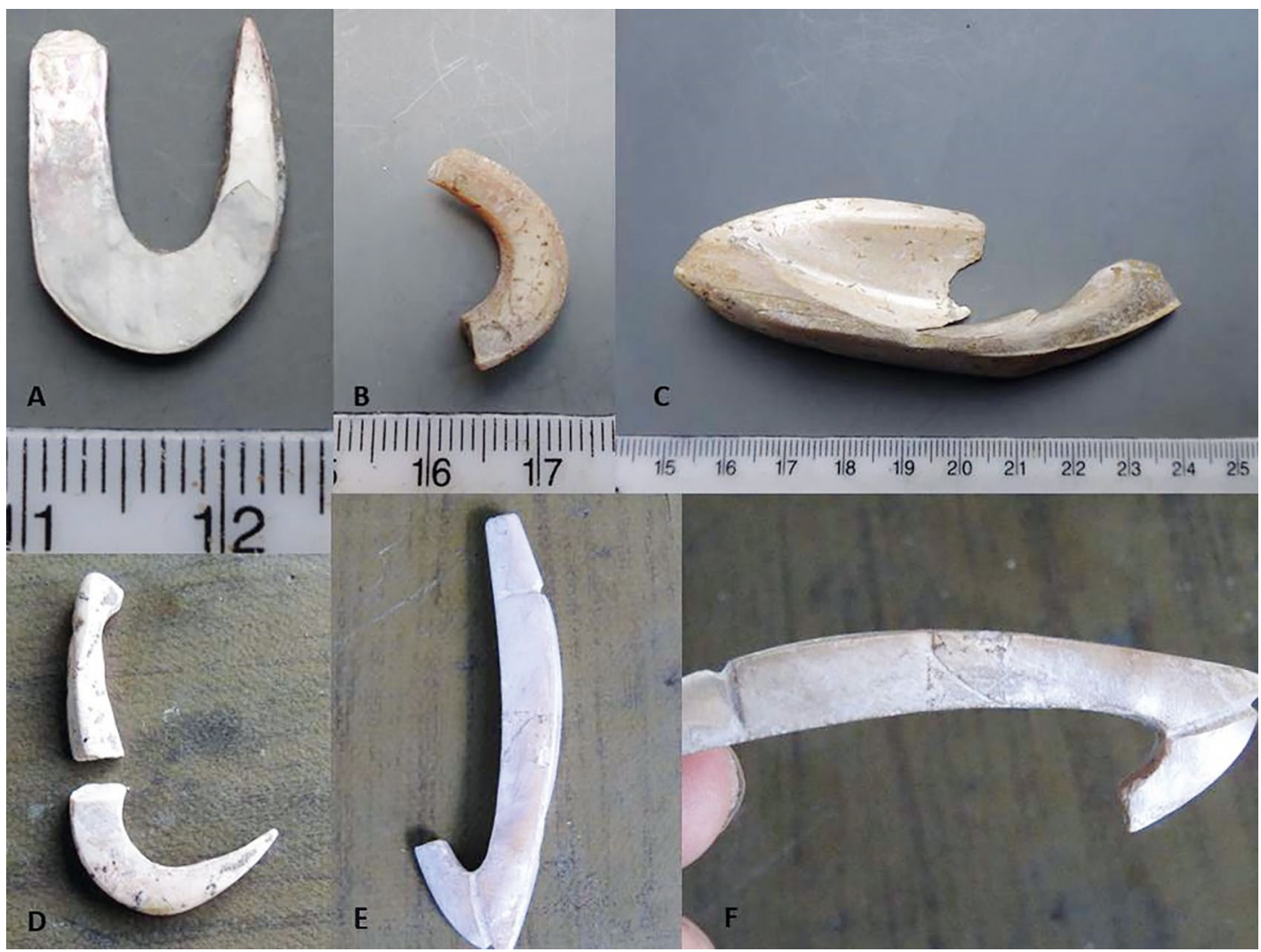

Figure 20.6. Fishhooks from Uripiv and Vao Islands.

(A) One-piece shell fishhook from Layer 3 (Area E), Uripiv; (B) one-piece shell fishhooks from Layer 2 (Area A), Uripiv; (C) an unfinished Trochus trolling lure tab from Layer 5 (Trench D), Uripiv; (D) one-piece shell hook from ST11, Vao; (E-F) broken one-piece trolling hook from TP19A, Vao.

Source: Photographs prepared by the authors.

\section{Lapita fishing strategies in Oceania: Technological and fish bone evidence}

With the addition of our Uripiv Lapita-age fish bone data from Vanuatu as well as other fish assemblages from Tamuarawai (EQS) on Emirau, New Ireland (Summerhayes et al. 2010), Naitabale in Fiji (Ishimura 2010), Nukuleka and Tufu Mahina on Tongatapu (Poulsen 1987), we are able to add more detail generalised trends in Lapita fishing strategies that build significantly on Butler's (1994) earlier work generated from nine sites. Here we compare the relative proportions of herbivores, omnivores and carnivores from 14 sites to indicate fish-capture strategies. The results present a much clearer pattern than before, which suggests that Lapita fishing practices were more homogeneous across Near and Remote Oceania than previously thought. This is indicated by most of these Lapita assemblages being comprised of similar frequencies of carnivores and herbivores/omnivores, although there were various degrees of higher ratios of carnivorous fish taxa in seven sites (Figure 20.7). The only exceptions are TK-4 on Tikopia and Lolokoka on Niuatoputapu, in which fish assemblages are dominated by herbivores/omnivores. 


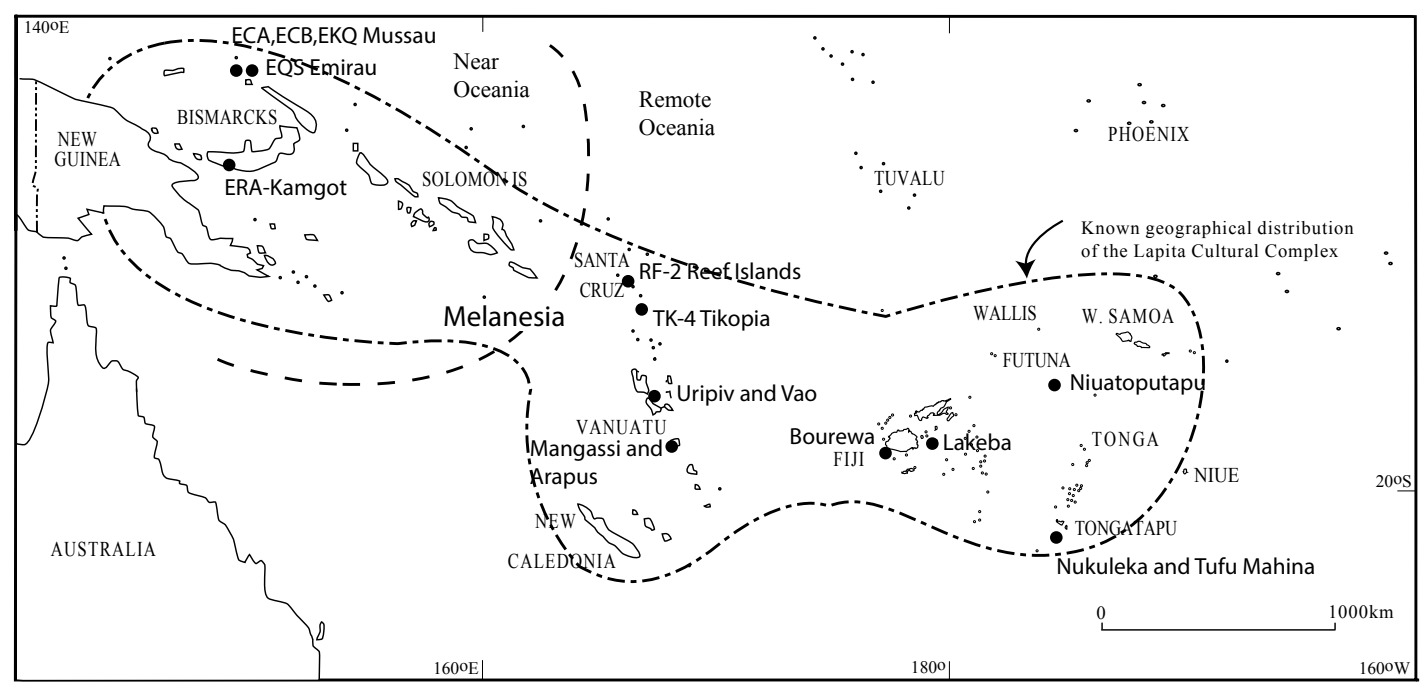

Figure 20.7. Location of Lapita sites with fish remains or fishhooks discussed.

Source: Illustration by the authors.

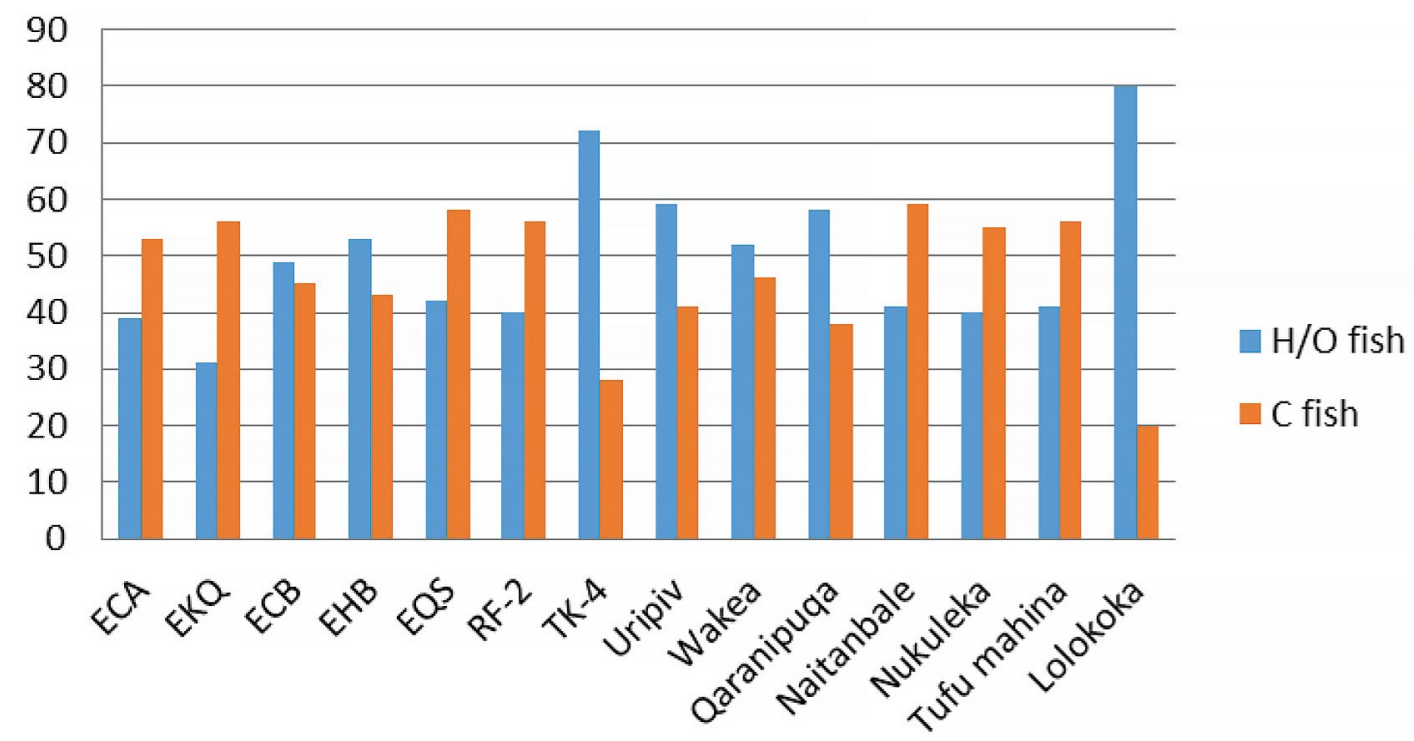

Figure 20.8. Relative proportion of fish remains by fish feeding strategies in 14 Lapita sites.

ECA, ECB, EHB, EKQ are located in the Mussau Islands; EQS is the Tamuarawai site on Emirau; RF-2 is located in the main Reef Islands of the Santa Cruz Group, with TK-4 located in Tikopia; Uripiv is located in Vanuatu; Wakea and Qaranipuqa are located on Lakeba, Fiji; Naitanbale located in Fiji; and Nukuleka and Tufu Mahina on Tongatapu.

Source: Chart prepared by the authors.

These new comparative data suggest three possibilities; (1) there are no clear differences in fish use and fish-capture methods between Western Lapita sites and Eastern Lapita sites regardless of marine environment, which would suggest broad-level societal structures with regards to fishing (e.g. similar gender divisions, social stratification); (2) differences in the ratios of herbivores/ omnivores to carnivores reflect human sociocultural preferences or the differential development of certain fishing technologies from region to region and over time. For example, the rather higher ratio of carnivorous fish species in many sites probably indicates a much greater importance and popularity of angling methods. This is confirmed by the presence of fishhooks and trolling lures from Lapita sites including those from Vao and Uripiv in Vanuatu. However, not all carnivorous 
fish species are captured by angling. This is the case with Labrids and Lethrinids, which are the most abundant carnivorous fish in Lapita sites that can also be easily captured by netting and spearing if encountered in shallow water. A third scenario (3) is that variation in local and regional marine ecologies is responsible for any variation in fish bone data. For example, the two exceptional Lapita sites, TK-4 and Lolokoka, located on Tikopia and Niuatoputapu, are likely to reflect this unique marine ecology with extensive shallow reefs and the dominance of herbivore/ omnivore fishes such as Scarids and Acanthurids.

In a summary of the Vanuatu sites we include the sites of Mangaasi, Arapus and Ponamla. The numbers of identifiable fish bones from the site of Ifo and the six other sites from Malakula were too small to contribute meaningfully to the overall picture. Uripiv has larger proportions of carnivorous taxa such as Labrids and Lethrinids, compared to the Post-Lapita Mangaasi and Ponamla sites, where Labrids and Serranids are the major carnivore species (see Table 20.7). Fishing during the immediately Post-Lapita period at Arapus appears to have been focused on a mix of herbivorous/omnivorous fishes such as Acanthurids, Scarids and Diodontids on the adjacent reef flat, using mass-harvesting fishing gear with secondary use of angling for Serranids, Lethrinids and Labrids (Bouffandeau et al. 2018). Lethrinids basically prefer to inhabit shallow sandy-bottom reef environments like those present at Uripiv. On the other hand, Serranids and Scarids prefer to inhabit rocky-bottom reefs. Thus, the Vanuatu data suggest that differences in fish taxonomic composition between sites are likely affected by the prevalent local marine environment, which appears to have changed little over time at these sites. However, much as at Uripiv, it does appear that fishing declined at many of these early coastal settlements during the Post-Lapita period in Vanuatu, possibly as a result of changing subsistence and settlement patterns, populations and/or resource depression.

Table 20.7. NISP and ratio of each fish family from three sites (Uripiv, Mangaasi, Ponamla) in Vanuatu.

\begin{tabular}{|c|c|c|c|c|c|c|c|}
\hline & Site & Uripiv & & Mangaasi & & Ponamla & \\
\hline & Island & Malakula & & Efate & & Efate & \\
\hline Таха & Diet & & $\%$ & & $\% *$ & & $\%{ }^{*}$ \\
\hline Diodontidae & Omnivore & 101 & $15 \%$ & $28(18)^{*}$ & $11 \%$ & $41(24)$ & $24 \%$ \\
\hline Scaridae & Herbivore & 124 & $18 \%$ & $118(71)$ & $42 \%$ & $28(23)$ & $23 \%$ \\
\hline Acanthuridae & Herbivore & 78 & $12 \%$ & $15(11)$ & $7 \%$ & $7(7)$ & $7 \%$ \\
\hline Balistidae & Omnivore & 73 & $11 \%$ & $7(6)$ & $4 \%$ & $5(4)$ & $4 \%$ \\
\hline Ostraciidae & Omnivore & 13 & $2 \%$ & - & - & $4(3)$ & $3 \%$ \\
\hline Kyophosidae & Herbivore & 5 & $1 \%$ & - & - & - & - \\
\hline Tetradontidae & Omnivore & 1 & - & - & - & - & - \\
\hline Pomacentridae & Omnivore & 1 & - & - & - & - & - \\
\hline Subtotal & & 396 & $59 \%$ & $168(106)$ & $62 \%$ & $85(61)$ & $61 \%$ \\
\hline Lethrinidae & Carnivore & 111 & $17 \%$ & $6(6)$ & $4 \%$ & $5(5)$ & $5 \%$ \\
\hline Labridae & Carnivore & 110 & $16 \%$ & $23(18)$ & $11 \%$ & $15(12)$ & $12 \%$ \\
\hline Serranidae & Carnivore & 15 & $2 \%$ & $27(23)$ & $14 \%$ & $12(11)$ & $11 \%$ \\
\hline Holocentridae & Carnivore & 10 & $2 \%$ & $7(7)$ & $4 \%$ & $8(7)$ & $7 \%$ \\
\hline Lutjanidae & Carnivore & 6 & $1 \%$ & $1(1)$ & $1 \%$ & 1(1) & $1 \%$ \\
\hline Carangidae & Carnivore & 7 & $1 \%$ & $2(2)$ & $1 \%$ & $4(3)$ & $3 \%$ \\
\hline Haemulidae & Carnivore & 7 & $1 \%$ & - & - & - & - \\
\hline Muraenidae & Carnivore & 6 & $1 \%$ & $1(1)$ & $1 \%$ & $1(1)$ & $1 \%$ \\
\hline Elasmobranch & Carnivore & 3 & - & - & - & - & - \\
\hline Muliidae & Carnivore & 2 & - & $4(4)$ & $2 \%$ & - & - \\
\hline Scorpanidae & Carnivore & - & - & $2(2)$ & $1 \%$ & - & - \\
\hline
\end{tabular}




\begin{tabular}{|l|l|c|c|c|c|c|c|}
\hline & Site & Uripiv & & Mangaasi & & Ponamla & \\
\hline & Island & Malakula & & Efate & & Efate & \\
\hline Taxa & Diet & & $\%$ & & $\%^{*}$ & & $\%^{*}$ \\
\hline Scombridae & Carnivore & - & - & - & - & - & - \\
\hline Belonidae & Carnivore & - & - & - & - & - & - \\
\hline subtotal & & 277 & $41 \%$ & $73(64)$ & $38 \%$ & $46(40)$ & $40 \%$ \\
\hline Others & & - & - & 16 & - & 10 & - \\
\hline NISP(MNI) & & 673 & - & $257(170)$ & - & $141(101)$ & - \\
\hline
\end{tabular}

" = based on MNI

$\because()=$ MNI

Source: Authors' summary.

A comparative view of fishing technology, mainly hooks and lures from Lapita sites, indicates some critical differences in technology by period and region. In terms of possible developments of Lapita fishing strategies or technologies, the past and current archaeological fish bone data tentatively indicate that the use of pelagic species-mainly Scombrids (tunas, mackerels, bonitos) - is more visible in Western Lapita sites in Near Oceania during the Early Lapita period. Only a few Scombrid bones were found or identified among the Lapita sites in Remote Oceania, including Vanuatu. However, the Vanuatu sites also produced one-piece trolling lures used for catching pelagic species such as tuna (see Table 20.6).

Table 20.8 lists other reported shell lure-hooks from other Lapita sites (Ishimura 2010; Kirch 1997, 2000; Summerhayes et al. 2010; Szabó 2010). First, regarding the possible Trochus one-piece lure-hooks, one complete specimen and some unfinished specimens have been excavated from Early Lapita sites like Talepakemalai on Eloaua Island in the Mussau group (Figure 20.9a-b) and Tamuarawai on Emirau (Figure 20.9c). The same type of Trochus one-piece hook is present in the Vao fishing gear assemblage (Figure 20.6e-f). These also match with the unfinished specimens from Uripiv (Figure 20.6c) and a broken Tridacna shell fishhook with a single hole from Bourewa in Fiji (Figure 20.9d). This indicates that the basic production technology is similar between Early Lapita examples and those associated with initial Lapita settlement of Vanuatu and Fiji. The existence of such Trochus trolling fishhooks in Vanuatu indicates that pelagic species were also captured by Lapita people in Vanuatu even if these pelagic species were not well represented in the archaeofaunal assemblages. A Tridacna shell fishhook with a single hole from Fiji might have been used as a two-piece hook, though its actual method of use and function is yet unclear.

Table 20.8. Excavated trolling hooks/lures from Western and Eastern Lapita sites.

\begin{tabular}{|l|l|l|l|l|}
\hline Fishhook type & Site-No & Material & Age & Reference \\
\hline One-piece trolling hook & Talepakemalai & Trochus sp. & Early Lapita & Kirch 1997 \\
\hline One-piece trolling hook & Talepakemalai & Trochus sp. & Early Lapita & Kirch 1997 \\
\hline One-piece trolling hook tab & Talepakemalai & Trochus sp. & Early Lapita & Kirch 1997 \\
\hline One-piece trolling hook tab & Talepakemalai & Trochus sp. & Early Lapita & Kirch 1997 \\
\hline One-piece trolling hook & Tamuarawai TP4 & Trochus sp. & Early Lapita & Summerhayes et al. 2010 \\
\hline One-/two-piece trolling hook? & Bourewa, Fiji & Tridacna sp. & Lapita & Ishimura 2010 \\
\hline
\end{tabular}

Source: Compiled by authors from references in table. 

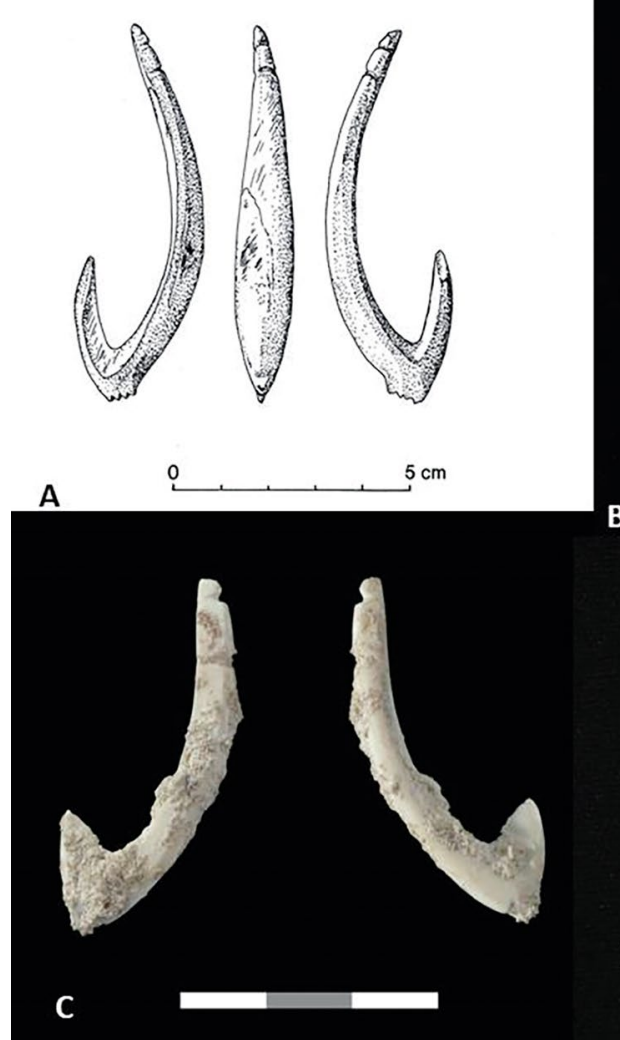

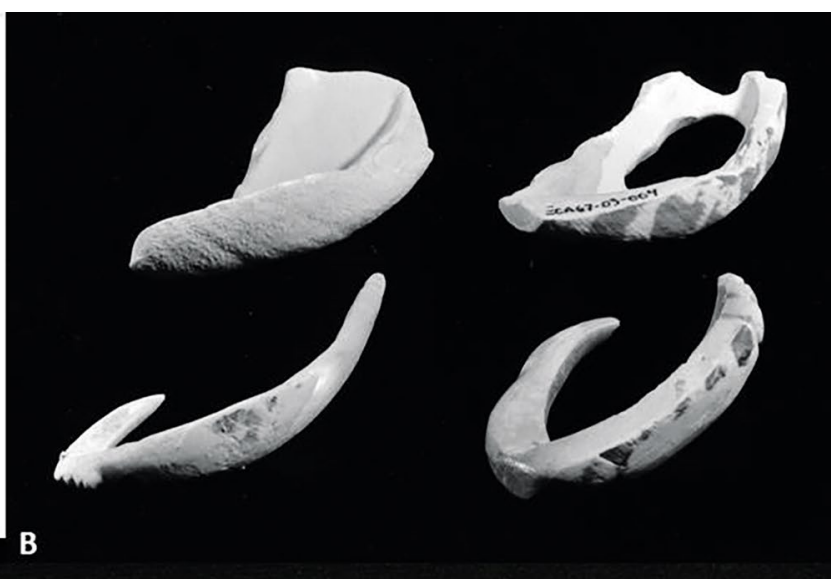

D

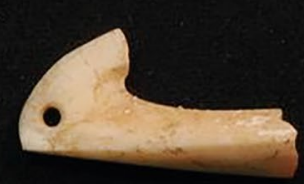

-

Figure 20.9. One-piece Trochus trolling hook-lures from Western Lapita sites and possible two-piece hook from Fiji.

(A) complete one-piece trolling hook from Mussau; (B) complete and unfinished trolling hooks from Mussau; (C) one-piece trolling hook from Tamuarawai on Emirau; (D) a possible two-piece trolling hook from Bourewa, Fiji.

Source: (A-B) Kirch 1997; (C) Summerhayes et al. 2010; (D) Ishimura 2010.

Uripiv and Vao are located close to deep-water channels and the current inhabitants also catch tuna, including skipjack, by trolling in such adjacent channels from boats with outboard motors (Figure 20.10). However, these one-piece Trochus trolling fishhooks have, to date, been mainly recovered from Lapita deposits. The data currently indicate that pelagic species were more actively captured during Early Lapita colonisation of Near Oceania and Vanuatu. This decline in pelagic fishing during later Post-Lapita periods could be related to the broadening of fishing strategies and the exploitation of a greater range of various near-shore marine resources in newly colonised islands. Trolling may have simply been a more important part of Lapita socioeconomic systems during the early exploration and open sea voyaging phase.

There are also differences and similarities between one-piece fishhooks from Near Oceania and Remote Oceania. One-piece fishhooks in Near Oceania at the Kamgot and Tamuarawai Lapita sites (Figure 20.11a-b, g) are bigger in size and are jabbing-type fishhooks (e.g. Szabó 2010; Summerhayes et al. 2010). The main axis of the shank and point of a jabbing-hook is parallel or sometimes the point is slightly curved (e.g. Sinoto 1991). A clearly identifiable jabbing-hook was also excavated from Uripiv (see Figure 20.6a or Figure 20.11c). Such jabbing-hooks are estimated to have been employed for catching fast-swimming fish such as tuna on the surface of shallow reef platforms, since the hooks are designed for quick extraction and the fisherman must pull the line quickly to avoid losing the fish. 

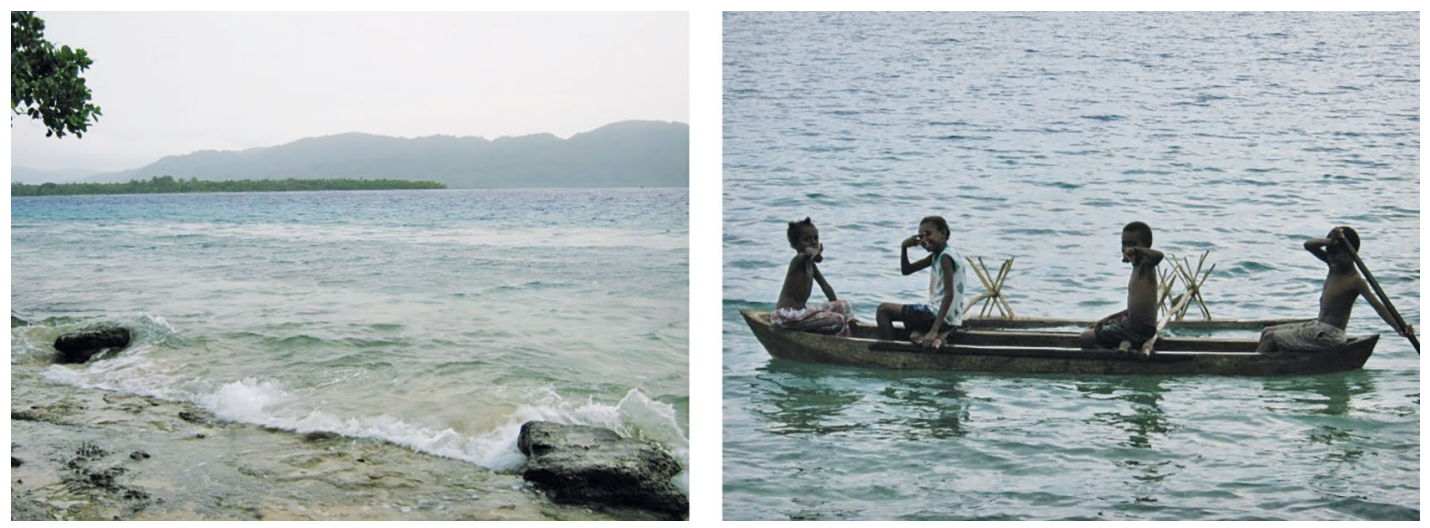

Figure 20.10. Contemporary Uripiv foreshore and canoes.

Source: Rintaro 0 no.

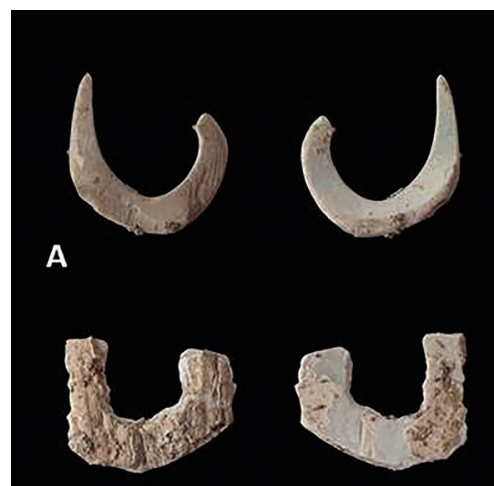

B

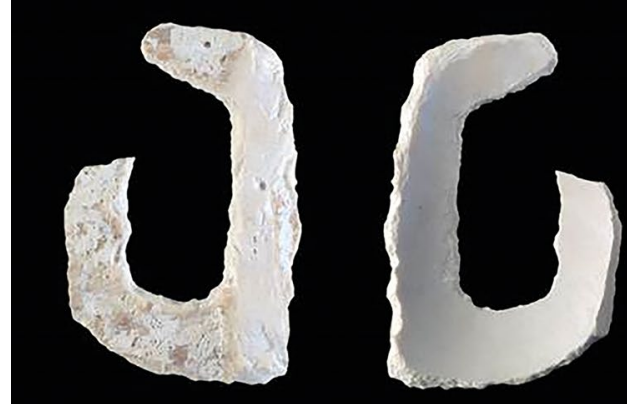

G

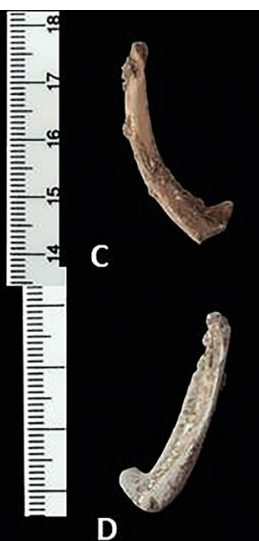

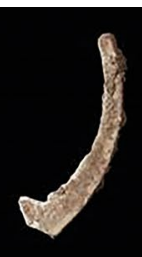

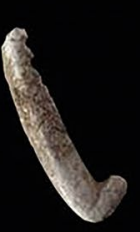

D

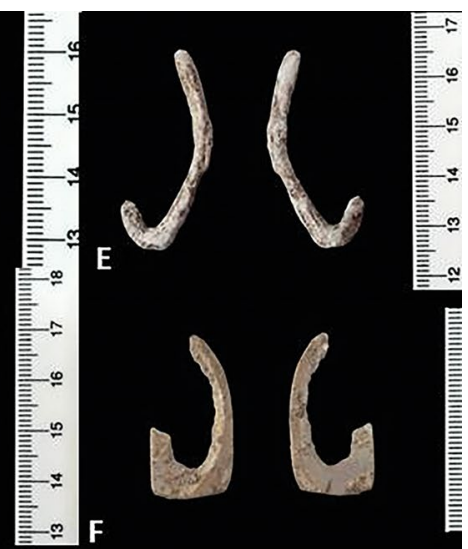

Figure 20.11. One-piece hooks from Western Lapita sites and Vanuatu.

(A-G) fishhooks from Near Oceania (Kamgot and Tamuarawai); (H) jabbing fishhook from Uripiv; (I) hook from Vao. Source: (A-G) provided by Glenn R. Summerhayes; (H-I) provided by Stuart Bedford.

Although the sample is very small, there does appear to be a change over time in Vanuatu fishhook technology where small-sized fishhooks during Late Lapita to Post-Lapita times increased in abundance. Corresponding to this pattern, the proportions of Labrids and Lethrinids also increased over time on Uripiv. If angling was partly used to catch these taxa, then it is logical that hook size should also become smaller. Although the data and information are still limited, smaller-sized fishhooks (Figure 20.11d-f) tend to be recovered in Remote Oceanic Lapita sites from Vanuatu, New Caledonia, Fiji, Tikopia and Anuta, rather than from Near Oceanian Lapita sites. Similarly, as in TK-4 on Tikopia, the percentage of smaller-sized carnivorous fish like 
Holocentrids also slightly increased in Remote Oceania Lapita sites (Green 1986). In terms of the material used for hooks, Trochus, Turbo and Tridacna shell were used in Far Western to Western Lapita sites, but Turbo shell fishhooks are less common in Remote Oceania sites and absent in Vanuatu, New Caledonia and Fiji as discussed by Szabó (2010:122). It is not certain if variations in fishing practices are the result of different localised marine environments or a result of changes across time and space in sociocultural practices during Lapita colonisation in Oceania. The Uripiv example within the context of other Vanuatu Lapita and Post-Lapita assemblages indicates that localised marine ecological conditions played an important role and that there was continuity from Lapita to Post-Lapita fishing practices over time despite a change in fishing technology.

\section{Conclusion}

These results add considerably to our understanding of Lapita fishing adaptations to marine environments in the region and how they persisted over several centuries during the Post-Lapita period. They suggest a diverse array of technology and capture methods, with similarities and differences between regions and temporal periods that may reflect a basic cultural homogeneity and differences in local marine habitats. However, more research is required in further regions within Vanuatu and the wider Pacific to provide the more detailed comparative data needed to understand continuity in fish taxonomic composition and change in technology over time and space. Vanuatu remains a critical region for such analyses due to its strategic location between the west and east of the Lapita distribution.

\section{Acknowledgements}

We thank the chiefs, landowners and communities of the small islands of north-east Malakula for their support and permission to carry out excavations in their areas. Numa Fred Longga, curator of the Malakula Cultural Centre was an exceptional guide throughout. Special thanks to Patrick V. Kirch, Glenn R. Summerhayes and Tomo Ishimura for providing original figures and pictures of fishhooks. Funding was provided variously by the Sasakawa Pacific Island Nations Fund; the Royal Society of New Zealand (Marsden Fast-Start 9011/3602128; 04-U00-007); a National Geographic Scientific Research Grant (7738-04) and the Australian Research Council (DP0556874 and DP0880789). All figures and tables were produced by the authors unless otherwise stated.

\section{References}

Bedford, S. 2003. The timing and nature of Lapita colonisation in Vanuatu: The haze begins to clear. In C. Sand (ed.), Pacific archaeology: Assessments and prospects. Proceedings of the conference for the 50th anniversary of the first Lapita excavation, Kone-Nouméa, 2002, pp. 147-158. Les cahiers de l'archéologie en Nouvelle-Calédonie 15. Département Archéologie, Service des Musées et du Patrimoine de Nouvelle-Calédonie, Nouméa.

Bedford, S. 2006. Pieces of the Vanuatu puzzle: Archaeology of the north, south and centre. Terra Australis 23. Pandanus Books, The Australian National University, Canberra. doi.org/10.22459/PVP.02.2007.

Bedford, S. 2007. Crucial first steps into Remote Oceania: Lapita in the Vanuatu archipelago. In S. Chiu and C. Sand (eds), From Southeast Asia to the Pacific. Archaeological perspectives on the Austronesian expansion and the Lapita Cultural Complex, pp. 185-213. Centre for Archaeological Studies, Research Centre of Humanities and Social Sciences. Academia Sinica, Taipei. 
Bedford, S., H. Buckley, F. Valentin, N. Tayles and N. Longga 2011. Lapita burials, a new Lapita cemetery and Post-Lapita burials from Malakula, northern Vanuatu, Southwest Pacific. Journal of Pacific Archaeology 2(2):26-48.

Bouffandeau, L., P. Béarez, S. Bedford, F. Valentin, M. Spriggs and E. Nolet 2018. Fishing at ArapusMangaasi, Efate, Vanuatu (2800-2200 BP): New methodological approaches and results. Journal of Archaeological Science, Reports 18:356-359. doi.org/10.1016/j.jasrep.2018.01.025.

Butler, V.L. 1988. Lapita fishing strategies: The faunal evidence. In P.V. Kirch and T.L. Hunt (eds), Archaeology of the Lapita Cultural Complex: A critical review, pp. 99-115. Thomas Burke Memorial Washington State Museum Research Report 5. Burke Museum, Seattle.

Butler, V.L. 1994. Fish feeding behaviour and fish capture: The case for variation in Lapita fishing strategies. Archaeology in Oceania 29:81-90. doi.org/10.1002/arco.1994.29.2.81.

Campos, F.Z. 2009. The ichthyoarchaeology of Batanes Islands, Northern Philippines. MA Thesis, University of Philippines, Manila.

Clark, G. and K. Szabó 2009. The fishbone remains. In G. Clark and A.J. Anderson (eds), The early prehistory of Fiji, pp. 213-230. Terra Australis 31. ANU E Press, Canberra. doi.org/10.22459/ TA31.12.2009.

Green, R.C. 1979. Lapita. In J.D. Jennings (ed.), The prehistory of Polynesia, pp. 27-60. Harvard University Press, Cambridge, Mass. doi.org/10.4159/harvard.9780674181267.c3.

Green, R.C. 1986. Lapita fishing: The evidence of site SE-RF-2 from the main Reef Islands, Santa Cruz Group, Solomons. In A. Anderson (ed.), Traditional fishing in the Pacific: Ethnographic and archaeological papers from the 15th Pacific Science Congress, pp. 19-35. Pacific Anthropological Records 37. Bernice P. Bishop Museum, Honolulu.

Hawkins, S., T.H. Worthy, S. Bedford, M. Spriggs, G. Clark, G. Irwin, S. Best and P. Kirch 2016. Ancient tortoise hunting in the Southwest Pacific. Nature: Scientific Reports 6:38317. doi.org/ $10.1038 /$ srep38317.

Horrocks, M. and S. Bedford 2005. Microfossil analysis of Lapita deposits in Vanuatu reveals introduced Araceae (aroids). Archaeology in Oceania 40:67-74. doi.org/10.1002/j.1834-4453.2005.tb00587.x.

Horrocks, M., S. Bedford and M. Spriggs 2009. A short note on banana (Musa) phytoliths in Lapita, immediately Post-Lapita and modern period archaeological deposits from Vanuatu. Journal of Archaeological Science 36:2048-2054. doi.org/10.1016/j.jas.2009.05.024.

Ishimura, T. 2010. Lapita archaeology. Keisui Press (in Japanese), Tokyo.

Kirch, P.V. 1988. The Talepakemalai Lapita site and Oceanic prehistory. National Geographic Research 4(3):328-342.

Kirch, P.V. 1997. The Lapita peoples: Ancestors of the Oceanic world. Blackwell, Oxford.

Kirch, P.V. 2000. On the road of the winds: An archaeological history of the Pacific Islands before European contact. University of California Press, Berkeley.

Kirch, P.V. and T.S. Dye 1979. Ethno-archaeology and the development of Polynesian fishing strategies. Journal of the Polynesian Society 88:53-76.

Kirch, P.V. and D.E. Yen 1982. Tikopia: The prehistory and ecology of a Polynesian Outlier. Bernice P. Bishop Museum Bulletin 238. Bishop Museum Press, Honolulu.

Kononenko, N., S. Bedford and C. Reepmeyer 2010. Functional analysis of late Holocene (Lapita) flaked and pebble stone artefacts from Vanuatu, Southwest Pacific. Archaeology in Oceania 45:13-20. doi.org/10.1002/j.1834-4453.2010.tb00073.x. 
Lambrides, A.B.J. and M.I. Weisler 2015a. Assessing protocols for identifying Pacific Island archaeological fish remains: The contribution of vertebrae. International Journal of Osteoarchaeology 25:838-848. doi.org/10.1002/oa.2354.

Lambrides, A.B.J. and M.I. Weisler 2015b. Applications of vertebral morphometrics in Pacific Island archaeological fishing studies. Archaeology in Oceania 50:53-70. doi.org/10.1002/arco.5059.

Layard, J. 1942. The stone men of Malekula: The small island of Vao. Chatto and Windus, London.

Leach B.F. 1986. A method for analysis of Pacific island fishbone assemblages and an associated database management system. Journal of Archaeological Science 13(2):147-159. doi.org/10.1016/0305-4403 (86)90004-X.

Leach, B.F. and A. Budec-Piric n.d. Arapus 1999 fish remains. Unpublished report.

Leach, B.F. and J.M. Davidson 1977. Fishing methods and seasonality at Paremata (N160/50). New Zealand Archaeological Association Newsletter 20(3):166-175.

Leach, B.F., J.M. Davidson and K. Fraser 1998. Analysis of fish bone from archaeological sites in Vanuatu. Museum of New Zealand Te Papa Tongarewa Technical Report 32. Museum of New Zealand Te Papa Tongarewa, Wellington.

Mafutaga-a-Toeaina-o-Atafu-i-Matauala-Porirua 2008. Hikuleo: I te Papa o Tautai. Steele Roberts, Wellington.

Masse, W.B. 1986. A millennium of fishing in the Palau Islands, Micronesia. In A. Anderson (ed.), Traditional fishing in the Pacific: Ethnographic and archaeological papers from the 15th Pacific Science Congress, pp. 85-117. Pacific Anthropological Records 37. Bernice P. Bishop Museum, Honolulu.

Masse, W.B. 1989. The archaeology and ecology of fishing in the Belau Islands, Micronesia. Unpublished PhD thesis, Southern Illinois University.

McAlister, A.J. 2002. Prehistoric fishing at Fakaofo, Tokelau: A case of resource depression on a small atoll. Unpublished MA thesis, University of Auckland, Auckland.

Nunn, P.D., R. Kumar, S. Matararaba, T. Ishimura, J. Seeto, S. Rayawa, S. Kuruyawa, A. Nasila, B. Oloni, A. Rati Ram, P. Saunivalu, P. Singh and E. Tegu 2004. Early Lapita settlement site at Bourewa, southwest Viti Levu Island, Fiji. Archaeology in Oceania 39:139-143. doi.org/10.1002/ j.1834-4453.2004.tb00571.x.

Nunn, P.D., R. Kumar, S. Matararaba and T. Ishimura 2006. The earliest human settlement in the Fiji Islands. Domodomo (Fiji Museum Quarterly) 19:27-33.

O'Connor, S., R. Ono and C. Clarkson 2011. Pelagic fishing at 42,000 years before the present and the maritime skills of modern humans. Science 334:1117-1121. doi.org/10.1126/science.1207703.

Ono, R. 2003. Prehistoric Austronesian fishing strategies: A comparison between Island Southeast Asia and the Lapita Cultural Complex. In C. Sand (ed.), Pacific archaeology: Assessments and prospects. Proceedings of the conference for the 50th anniversary of the first Lapita excavation, Kone-Nouméa, 2002, pp. 191-201. Les cahiers de l'archéologie en Nouvelle-Calédonie 15. Département Archéologie, Service des Musées et du Patrimoine de Nouvelle-Calédonie, Nouméa.

Ono, R. 2004. Prehistoric fishing at Bukit Tengkorak, east coast of Borneo Island. New Zealand Journal of Archaeology 24:77-106.

Ono, R. 2006. Marine exploitations and subsistence strategies in the Celebes Sea: An ethnoarchaeological approach for area studies. Unpublished PhD thesis, Sophia University (in Japanese).

Ono, R. 2009. Ethnoarchaeology in coral seas. Quarterly of Archaeological Studies 55(4):75-94 (in Japanese). 
Ono, R. 2010. Ethno-archaeology and the early Austronesian fishing strategies in near-shore environments. Journal of the Polynesian Society 119(3):269-314.

Ono, R. 2011. Marine exploitation and fishing strategies in Celebes Sea: Area studies in maritime Southeast Asia. Kyoto University Press, Kyoto (in Japanese).

Ono, R. and D. Addison 2009. Ethnoecology and Tokelauan fishing lore from Atafu atoll, Tokelau. SPC Traditional Marine Resource Management and Knowledge Information Bulletin 26:3-22.

Ono, R. and G. Clark 2010. A 2500-year record of marine resource use on Ulong Island, Republic of Palau. International Journal of Osteoarchaeology 22(6):637-654. doi.org/10.1002/oa.1226.

Ono, R. and M. Intoh 2011. Island of pelagic fishermen: Temporal changes in prehistoric fishing on Fais, Micronesia. Journal of Island and Coastal Archaeology 6:255-286. doi.org/10.1080/15564894.2010. 540531.

Poulsen, J. 1987. Early Tongan prehistory: The Lapita period on Tongatapu and its relationships. Two volumes. Terra Australis 12. Department of Prehistory, RSPacS, The Australian National University, Canberra.

Reinman, F.M. 1965. Maritime adaptation: An aspect of Oceanic economy. Unpublished PhD thesis, University of California, Los Angeles.

Reinman, F.M. 1967. Fishing: An aspect of Oceanic economy. An archaeological approach. Fieldiana Anthropology 54(2):95-208.

Robin, C., M. Monzier and J.-P. Eissen 1993. Giant tuff cone and 12-km-wide associated caldera at Ambrym Volcano (Vanuatu, New Hebrides Arc). Journal of Volcanology and Geothermal Research 55:225-238. doi.org/10.1016/0377-0273(93)90039-T.

Samper Caro, S.C., S. O’Connor, J. Louys, S. Hawkins and M. Mahirta 2016. Human maritime subsistence strategies in the Lesser Sunda Islands during the terminal Pleistocene-Early Holocene: New evidence from Alor, Indonesia. Quaternary International 416:64-79. doi.org/10.1016/j.quaint. 2015.07.068.

Sinoto, Y. 1991. A revised system for the classification and coding of Hawaiian fishhooks. Bishop Museum Occasional Papers 31:85-105.

Summerhayes, G.R., E. Matisoo-Smith, H. Mandui, J. Allen, J. Specht, N. Hogg and S. McPherson 2010. Tamuarawai (EQS): An Early Lapita site on Emirau, New Ireland, PNG. Journal of Pacific Archaeology 1(1):62-75.

Szabó, K., A. 2010. Shell artefacts and shell-working within the Lapita Cultural Complex. Journal of Pacific Archaeology 1(2):115-127.

Szabó, K. and G.R. Summerhayes 2002. Worked shell artefacts-new data from Early Lapita. In S. Bedford, C. Sand and D. Burley (eds), Fifty years in the field: Essays in honour of Richard Shutler Jr's archaeological career, pp. 91-100. New Zealand Archaeological Association Monograph 25. New Zealand Archaeological Association, Auckland.

Vogel Y. 2005. Ika. Unpublished MA thesis, Department of Anthropology, University of Otago.

Walter, R. 1989. Lapita fishing strategies: A review of the archaeological and linguistic evidence. Pacific Studies 13:127-149.

Wright, A. and A.H. Richards 1985. A multispecies fishery associated with coral reefs in the Tigak Islands, Papua New Guinea. Asian Marine Biology 2:69-84.

Zar, J.H. 2010. Biostatistical analysis. Pearson Prentice Hall, New Jersey. 
This text is taken from Debating Lapita: Distribution, Chronology, Society and Subsistence, edited by Stuart Bedford and Matthew Spriggs, published 2019 by ANU Press,

The Australian National University, Canberra, Australia.

doi.org/10.22459/TA52.2019.20 